\title{
Potential Improvement in Fill Factor of Lead-Halide Perovskite Solar Cells
}

\author{
$\operatorname{AUTHOR}(S):$ \\ Kim, Do Hyung; Ohkita, Hideo
}

CITATION:

Kim, Do Hyung ... [et al]. Potential Improvement in Fill Factor of LeadHalide Perovskite Solar Cells. Solar RRL 2017, 1(6): e201700027.

\section{ISSUE DATE:}

2017-06

URL:

http://hdl.handle.net/2433/225282

\section{RIGHT:}

This is the accepted version of the following article: [Hyung Do Kim, Hideo Ohkita. Potential Improvement in Fill Factor of Lead - Halide Perovskite Solar Cells. Solar RRL, Volume 1, Issue 6, June 2017, e201700027.], which has been published in final form at https://doi.org/10.1002/solr.201700027. This article may be used for non-commercial purposes in accordance with Wiley Terms and Conditions for Self-Archiving.; The full-text file will be made open to the public on 7 June 2018 in accordance with publisher's 'Terms and Conditions for Self-Archiving'.; This is not the published version. Please cite only the published version.; この論文は出版社版でありません。引用の際には出版社版 をご確認ご利用ください。 
DOI: 10.1002/ ((please add manuscript number))

Article type: Communications

Potential Improvement in Fill Factor of Lead-Halide Perovskite Solar Cells

Hyung Do Kim and Hideo Ohkita, *

H. D. Kim and Prof. H. Ohkita

Department of Polymer Chemistry

Graduate School of Engineering

Kyoto University

Katsura, Nishikyo, Kyoto 615-8510, Japan

E-mail: ohkita@photo.polym.kyoto-u.ac.jp

Keywords: organic-inorganic perovskites, fill factors, series resistances, parallel resistances, ideality factor 


\title{
WILEY-VCH
}

\begin{abstract}
In this study, the origin of fill factor (FF) in lead-halide perovskite solar cells is discussed based on different thickness of 2,2',7,7'-tetrakis( $N, N$-di-p-methoxyphenylamine)-9,9-spirobifluorene (spiro-OMeTAD) as a hole-transporting layer (HTL). As the thickness of HTL is decreased, the FF increases and hence the photovoltaic performance is also improved. This is mainly ascribed to the reduced series resistance with decreasing HTL thickness. Such improvement in FF is examined on the basis of an empirical equation for FF with the diode and photovoltaic parameters. As a result, the thickness-dependent FF can be well explained by this equation. The potential improvements in FF and PCE are further discussed on the basis of the empirical equation.
\end{abstract}




\section{WILEY-VCH}

\section{Introduction}

Organic-inorganic perovskites based on lead halides have attracted a great deal of interest as one of the most promising materials for next-generation photovoltaic devices because they exhibit excellent optoelectronic properties, such as direct bandgap with high absorption coefficient, high charge carrier mobility, low exciton binding energy, and long diffusion length and lifetime of charge carriers despite being processed through solution processes at room temperature. ${ }^{[1-5]}$ Thus, intensive research efforts have been devoted not only to optimizing the device architecture but also to preparing high-quality perovskite layers with superior reproducibility to improve the power conversion efficiency (PCE) of perovskite solar cells..$^{[3,4,6-}$

9] As a result, the perovskite solar cells have shown remarkable improvements in the PCE from $3.8 \%$ in $2009^{[10]}$ to more than $22 \%$ in $2016 .^{[6,11]}$ Further improvements are still anticipated from the academic and commercial points of view. As such, it is of vital importance to discuss marginal efficiency of perovskite solar cells.

Highly efficient photovoltaic parameters have been reported for lead-halide perovskite solar cells in the last few years. The short-circuit current density $\left(J_{\mathrm{SC}}\right)$ has been improved up to $\approx 24 \mathrm{~mA} \mathrm{~cm}^{-2}$ for the device with a thick active layer $(\approx 500 \mathrm{~nm}),{ }^{[7-9,12]}$ which is almost comparable to the maximum photocurrent taking into account the reflection loss of incoming light. ${ }^{[13]}$ The open-circuit voltage $\left(V_{\mathrm{OC}}\right)$ has been reported to be typically in the range of 0.90 $1.24 \mathrm{~V}$ at room temperature, ${ }^{[14-17]}$ which are lower by about $0.4-0.7 \mathrm{eV}$ than their bandgap $\left(E_{\mathrm{g}}\right)$ of $\approx 1.6 \mathrm{eV}^{[4,17,18]}$ As reported previously, ${ }^{[8,19-21]}$ this voltage loss is ascribed to direct recombination and trap-assisted Shockley-Read-Hall (SRH) recombination, the latter of which is dependent upon the trap density $N_{\mathrm{t}}$ in perovskite active layers. We have shown that $V_{\mathrm{OC}}$ could be improved up $\approx 1.3 \mathrm{~V}$ if trap density were reduced to $N_{\mathrm{t}}<10^{13} \mathrm{~cm}^{-3}{ }^{[7]}$ The fill factor (FF) has been reported to be in the range of $0.70-0.85$ for efficient perovskite solar cells. ${ }^{[14-17,22-24]}$ However, most of them are still dependent on the voltage sweep direction because of $J-V$ hysteresis. Consequently, it has been difficult to discuss the FF of perovskite solar cells 


\section{WILEY-VCH}

quantitatively. In other words, quantitative analyses of the FF are highly required to discuss the marginal efficiency of perovskite solar cells.

In this study, we discuss the limiting factors in FF of lead-halide perovskite solar cells with different thicknesses of 2,2',7,7'-tetrakis( $N, N$-di-p-methoxyphenylamine)-9,9-spirobifluorene (spiro-OMeTAD) employed as a hole-transporting layer (HTL). With decreasing HTL thickness, FF increased and hence the photovoltaic performance was also improved. This is ascribed mainly to the smaller series resistance with decreasing HTL thickness. We examined this improvement in FF on the basis of an empirical equation for FF with the diode and photovoltaic parameters. As a result, we found that the thickness dependence of FF can be well explained by this equation. Thus, we further discuss the potential improvement in FF and PCE on the basis of the empirical equation. 


\section{WILEY-VCH}

\section{Results and Discussion}

Figure 1a shows the $J-V$ characteristics of perovskite solar cells based on dense $\mathrm{TiO}_{2}$ with different HTL thickness, which were measured from 1.1 to $-0.10 \mathrm{~V}$ (reverse scan) with a delay time of $1 \mathrm{~s}$ under AM $1.5 \mathrm{G}$ simulated solar illumination with $100 \mathrm{~mW} \mathrm{~cm}{ }^{-2}$. All the devices exhibited highly reproducible photovoltaic performance. As summarized in Table 1, the $J_{\mathrm{SC}}$ and $V_{\mathrm{OC}}$ were almost independent of the HTL thickness. On the other hand, the FF increased with decreasing HTL thickness. As shown in Figure 1b, the external quantum efficiency (EQE) was as high as more than $90 \%$ over the broad wavelength from 400 to $750 \mathrm{~nm}$, which is consistent with the $J_{\mathrm{SC}}$ observed $\left(\approx 24 \mathrm{~mA} \mathrm{~cm}^{-2}\right)$. As shown in Figure $\mathrm{S} 1$ (see the Supporting Information), the $J_{\mathrm{SC}}$ and $V_{\mathrm{OC}}$ were almost independent of the scan directions while the $\mathrm{FF}$ observed for the forward scan $(-0.1$ to $1.1 \mathrm{~V})$ was smaller by about $7 \%$ than those for the reverse scan $(1.1$ to $-0.10 \mathrm{~V})$. Therefore, we should consider the hysteresis effect to discuss the FF quantitatively as described later.

First, we analyzed the $J-V$ characteristics in the dark on the basis of the equivalent circuit model to evaluate the series resistance $R_{\mathrm{S}}$ and the parallel resistance $R_{\mathrm{p}}$. In this model, the current density $J$ is given by ${ }^{[25,26]}$

$$
J=J_{0}\left\{\exp \left[\frac{q\left(V-J R_{\mathrm{s}}\right)}{n_{\mathrm{id}} k_{\mathrm{B}} T}\right]-1\right\}+\frac{V-J R_{\mathrm{s}}}{R_{\mathrm{p}}}-J_{\mathrm{ph}}
$$

where $J_{0}$ is the saturation current density at reverse bias, $q$ is the elementary charge, $n_{\text {id }}$ is the ideality factor, $k_{\mathrm{B}}$ is the Boltzmann constant, $T$ is the absolute temperature, and $J_{\mathrm{ph}}$ is the photocurrent density. Here, as shown in Figure 2a and Figure S2, the ideality factor $n_{\text {id }}$ was separately evaluated from a slope in $V_{\mathrm{OC}}$ plotted against the logarithm of $J_{\mathrm{SC}}$ based on Equation (2) rather than from the $J-V$ characteristics in the dark because the $J-V$ characteristics in the dark are strongly affected by both the $R_{\mathrm{s}}$ and $R_{\mathrm{p}}$ resistances. ${ }^{[25,26]}$

$$
V_{\mathrm{OC}}=\frac{n_{\mathrm{id}} k_{\mathrm{B}} T}{q} \ln \left(\frac{J_{\mathrm{SC}}}{J_{0}}\right)
$$




\section{WILEY-VCH}

As summarized in Table 2, the $n_{\mathrm{id}}$ was evaluated to be 1.6 for the forward scan and 1.3 for reverse scan, which were independent of the HTL thickness. By using the $n_{\text {id }}$ obtained, both $R_{\mathrm{S}}$ and $R_{\mathrm{p}}$ resistances were evaluated from the $J-V$ characteristics in the dark with Equation (1) as shown in Figure S3. As summarized in Table 2, the $R_{\mathrm{p}}$ resistance was more than $10^{5} \Omega \mathrm{cm}^{2}$ for all the HTL thicknesses. This is probably because the perovskite films prepared are dense and pin-hole free enough to suppress the leakage current. On the other hand, as shown in Figure $2 \mathrm{~b}$, the $R_{\mathrm{s}}$ resistance monotonically decreases with decreasing HTL thickness from 310 to 170 $\mathrm{nm}$ and reaches $3.4 \Omega \mathrm{cm}^{2}$ at an HTL thickness of $0 \mathrm{~nm}$. From the slope of the thicknessdependent $R_{\mathrm{S}}$ component, the conductivity is evaluated to be $5.6 \times 10^{-6} \mathrm{~S} \mathrm{~cm}^{-1}$, which is in good agreement with that evaluated for spiro-OMeTAD films as shown in Figure S4. These values are also comparable to the conductivity reported for spiro-OMeTAD films exposed in air for 20 min. ${ }^{[27]}$ We therefore ascribe the thickness-dependent $R_{\mathrm{S}}$ component to the film resistance of the HTL material. The remaining constant component $\left(3.4 \Omega \mathrm{cm}^{2}\right)$ is probably due to the film resistance of d- $-\mathrm{TiO}_{2}$ layer and the contact resistances at the interfaces. The resistance of d- $\mathrm{TiO}_{2}$ layer has been reported to be $\approx 0.4 \Omega \mathrm{cm}^{2}$ for a thickness of $40 \mathrm{~nm}$, which is much smaller than the constant component observed. ${ }^{[28]}$ This suggests that the constant fraction is mainly due to the contact resistances rather than the film resistance of $\mathrm{d}-\mathrm{TiO}_{2}$ layer.

To discuss how each diode parameter impacts on the FF, we analyzed the FF by using an empirical equation with the experimental data obtained. The FF in the ideal solar cells with a negligibly small series resistor $\left(R_{\mathrm{S}} \approx 0\right)$ and an ideal parallel resistor $\left(R_{\mathrm{p}} \rightarrow \infty\right)$ is represented by ${ }^{[29-31]}$

$$
\mathrm{FF}_{0}=\frac{v_{\mathrm{OC}}-\ln \left(v_{\mathrm{OC}}+0.72\right)}{v_{\mathrm{OC}}+1}
$$

where $v_{\mathrm{OC}}$ is the dimensionless voltage $v_{\mathrm{OC}}=q V_{\mathrm{OC}} / n_{\mathrm{id}} k_{\mathrm{B}} T$. On the other hand, the FF in the practical photovoltaics devices is dependent on both $R_{\mathrm{s}}$ and $R_{\mathrm{p}}$ resistances and thus typically expressed by ${ }^{[29-31]}$ 


$$
\mathrm{FF}=\mathrm{FF}_{\mathrm{s}}\left(1-\frac{v_{\mathrm{OC}}+0.7}{v_{\mathrm{OC}}} \frac{\mathrm{FF}_{\mathrm{s}}}{r_{\mathrm{p}}}\right)
$$

where $\mathrm{FF}_{\mathrm{s}}$ is given by

$$
\mathrm{FF}_{\mathrm{s}}=\mathrm{FF}_{0}\left(1-1.1 r_{\mathrm{s}}\right)+\frac{r_{\mathrm{s}}^{2}}{5.4}
$$

Here, $r_{\mathrm{s}}$ and $r_{\mathrm{p}}$ are the normalized resistances, which are given by $r_{\mathrm{s}}=J_{\mathrm{SC}} R_{\mathrm{S}} / V_{\mathrm{OC}}$ and $r_{\mathrm{p}}=$ $J_{\mathrm{SC}} R_{\mathrm{p}} / V_{\mathrm{OC}}$, respectively. We calculated the $\mathrm{FF}$ in all the perovskite devices by using Equation (4) with the experimental data evaluated. As summarized in Table 3, the FF calculated is in good agreement with the FF measured within an error of less than about $6 \%$. We note that this evaluation is still valid for the devices with a different $V_{\mathrm{OC}}$ (see the Supporting Information). This finding indicates that this equation is valid for the estimation of FF even with hysteresis and hence can predict the upper limit of FF in lead-halide perovskite solar cells.

Figure 3 shows the FF calculated by Equation (4) with different $R_{\mathrm{s}}$ and $R_{\mathrm{p}}$ resistances. Here, the photovoltaic parameters were employed for the best device measured under the forward scan: $J_{\mathrm{SC}}=23.8 \mathrm{~mA} \mathrm{~cm}^{-2}, V_{\mathrm{OC}}=1.06 \mathrm{~V}$, and $n_{\mathrm{id}}=1.6$. Note that the other contour maps of $\mathrm{FF}$ calculated for the reverse scan and for the perovksite devices with $N_{\mathrm{t}}<10^{13} \mathrm{~cm}^{-3}$ are illustrated in Figure S5. As shown in Figure 3, the FF is dependent only on the $R_{\mathrm{S}}$ where the $R_{\mathrm{p}}$ is larger than $10^{5} \Omega \mathrm{cm}^{2}$. Under such large $R_{\mathrm{p}}$, the FF remains constant even with increasing $R_{\mathrm{p}}$ but still increases from 0.64 to 0.84 with decreasing $R_{\mathrm{S}}$ resistance from 10 to $0.1 \Omega \mathrm{cm}^{2}$. This indicates that the FF in perovskite devices studied is primarily dependent on the $R_{\mathrm{S}}$ resistance rather than the $R_{\mathrm{p}}$ resistance because the $R_{\mathrm{p}}$ resistance is enough large $>10^{5} \Omega \mathrm{cm}^{2}$ regardless of the HTL thickness. We therefore conclude that the increased FF in perovksite solar cells is mainly due to the decreased $R_{\mathrm{s}}$ resistance with decreasing HTL thickness. As shown in the figure, the FF could be increased up to $\approx 0.83$ if the $R_{\mathrm{S}}$ resistance were reduced to $\approx 0.5 \Omega \mathrm{cm}^{2}$ that is reported for crystalline silicon solar cells, ${ }^{[32-35]}$ and thus PCE could be improved to $\approx 21 \%$. As reported previously, the conductivity of spiro-OMeTAD can be improved up to $\approx 10^{-3} \mathrm{~S} \mathrm{~cm}^{-1}$ by using a 


\section{WILEY-VCH}

dicationic salt of spiro-OMeTAD (spiro-(TFSI) 2$).{ }^{[36]}$ If such a highly conductive HTL material is empolyed, the $R_{\mathrm{s}}$ resistance could be reduced to $\approx 3.4 \Omega \mathrm{cm}^{2}$ as shown in Figure $\mathrm{S} 6$ and hence FF could be improved to 0.77 . To achieve $R_{\mathrm{S}}<1 \Omega \mathrm{cm}^{2}$ comparable to that of crystalline silicon solar cells, the contact resistances at the interfaces should be reduced to $<1 \Omega \mathrm{cm}^{2}$.

Finally, we discuss the potential improvement in $\mathrm{FF}$ in terms of $N_{\mathrm{t}}$ in $\mathrm{CH}_{3} \mathrm{NH}_{3} \mathrm{PbI}_{3}$ perovskite solar cells. In this estimation, the $J_{\mathrm{SC}}$ was fixed to $24 \mathrm{~mA} \mathrm{~cm}{ }^{-2}$ as an upper limit. As reported previously, both $V_{\mathrm{OC}}$ and $n_{\mathrm{id}}$ are dependent on the $N_{\mathrm{t}}$ in the perovskite layer under the direct and SRH recombinations. ${ }^{[7]}$ Consequently, the FF is also dependent on the $N_{\mathrm{t}}$ because it is a function of $J_{\mathrm{SC}}, V_{\mathrm{OC}}, n_{\mathrm{id}}, R_{\mathrm{s}}$, and $R_{\mathrm{p}}$ as shown in Equation (4). As shown in Figure 4, $n_{\mathrm{id}}$ decreases to unity with decreasing $N_{\mathrm{t}}$, suggesting that the direct recombination is dominant at $N_{\mathrm{t}}<10^{13} \mathrm{~cm}^{-3}$. For the resistances observed $\left(R_{\mathrm{s}}=6.0 \Omega \mathrm{cm}^{2}\right.$ and $\left.R_{\mathrm{p}}=1.0 \times 10^{5} \Omega \mathrm{cm}^{2}\right)$, the FF increases from 0.68 to 0.79 with decreasing $N_{\mathrm{t}}$ from $10^{16}$ to $10^{13} \mathrm{~cm}^{-3}$, and hence the PCE could be improved to $\approx 24 \%$. If it is assumed that $R_{\mathrm{s}}=0.5 \Omega \mathrm{cm}^{2}$, which is reported for crystalline silicon solar cells, ${ }^{[32-35]}$ the FF could be increased from 0.79 to 0.89 with decreasing $N_{\mathrm{t}}$ from $10^{16}$ to $10^{13} \mathrm{~cm}^{-3}$, and hence the PCE could be improved to $\approx 27 \%$ as summarized in Table 4 . We therefore conclude that the FF in perovskite solar cells is strongly dependent on both $N_{\mathrm{t}}$ and $R_{\mathrm{S}}$ resistance, and thus could be improved up to $\approx 0.90$ if the perovskite solar cells can be prepared with an extremely low $N_{\mathrm{t}}$ of $<10^{13} \mathrm{~cm}^{-3}$ together with a low $R_{\mathrm{S}}$ of $<1 \Omega \mathrm{cm}^{2}$. 


\section{WILEY-VCH}

\section{Conclusions}

We studied the FF of $\mathrm{CH}_{3} \mathrm{NH}_{3} \mathrm{PbI}_{3}$ perovskite solar cells with different HTL thicknesses. Both the $J_{\mathrm{SC}}$ and $V_{\mathrm{OC}}$ were almost independent of the HTL thickness whereas the FF was monotonically improved with decreasing HTL thickness. The $R_{\mathrm{s}}$ and $R_{\mathrm{p}}$ resistances were evaluated from the $J-V$ characteristics in the dark on the basis of the equivalent circuit model. The $n_{\mathrm{id}}$ was evaluated from the intensity dependence of $V_{\mathrm{OC}}$. As a result, we found that the improvement in FF is mainly due to the reduced series resistance with decreasing HTL thickness. More importantly, we found that the FF can be reproduced by using an empirical equation for FF with the diode and photovoltaic parameters experimentally obtained. On the basis of this equation, the FF could be improved up to $\approx 0.83$ if the $R_{\mathrm{S}}$ resistance was reduced to $\approx 0.5 \Omega \mathrm{cm}^{2}$ that reported for crystalline silicon devices, resulting in a high PCE of $\approx 21 \%$. To achieve such a low $R_{\mathrm{s}}$, it is required to employ highly conductive HTL materials (e.g. $\approx 10^{-3} \mathrm{~S}$ $\mathrm{cm}^{-1}$ ) and also to reduce the contact resistances at the interfaces to $<1 \Omega \mathrm{cm}^{2}$. The FF could be increased up to 0.79 if the $N_{\mathrm{t}}$ were reduced to $<10^{13} \mathrm{~cm}^{-3}$ and hence PCE could be improved to $\approx 24 \%$. Furthermore, the FF could be increased to $\approx 0.9$ if the $N_{\mathrm{t}}$ were reduced to $<10^{13} \mathrm{~cm}^{-3}$ and the $R_{\mathrm{s}}$ was reduced to those of crystalline silicon solar cells. We therefore emphasize that $\mathrm{CH}_{3} \mathrm{NH}_{3} \mathrm{PbI}_{3}$ perovskite solar cells have the potential to exhibit the theoretical limit of photovoltaic performance if they could be prepared with both an extremely low $N_{\mathrm{t}}$ of $<10^{13}$ $\mathrm{cm}^{-3}$ and a low $R_{\mathrm{s}}$ of $<1 \Omega \mathrm{cm}^{2}$. As such, our quantitative analysis gives a guideline for further enhancement of FF in perovskite solar cells and thus high PCE. 


\section{WILEY-VCH}

\section{Experimental Section}

Materials and Sample Preparation: A methanol solution of methylamine (90 mL, 40\%, 0.882 M; Wako Pure Chemical Industries, Ltd.) was added drop wise over 10 min to an aqueous solution of HI (96.9 mL, 57 wt\%, 1.29 M; Wako Pure Chemical Industries Ltd., Japan) in a 500 $\mathrm{mL}$ round bottom flask at $0{ }^{\circ} \mathrm{C}$, and then stirred for $2 \mathrm{~h}$. The precipitates were recovered by evaporation at $50{ }^{\circ} \mathrm{C}$ for $30 \mathrm{~min}$. The resultant yellowish raw products were dissolved in ethanol, recrystallized from diethyl ether, and then finally filtered. These steps were repeated three times. After filtration, the white solid products $\mathrm{CH}_{3} \mathrm{NH}_{3} \mathrm{I}$ were dried at $60^{\circ} \mathrm{C}$ in a vacuum oven for 24 h. Stock solutions $\left(\mathrm{CH}_{3} \mathrm{NH}_{3} \mathrm{PbI}_{3}\right)$ of $55 \mathrm{wt} \%\left(1160 \mathrm{mg} \mathrm{mL}^{-1}\right)$ were prepared by mixing $\mathrm{CH}_{3} \mathrm{NH}_{3} \mathrm{I}$ with purified $\mathrm{PbI}_{2}$ (L0279 for perovskite precursor, Tokyo Chemical Industry Co., Ltd.) at a molar ratio of 1 to 1 in anhydrous $N, N$-dimethylformamide (DMF, 99.8\%, SigmaAldrich) and then stirred at $70{ }^{\circ} \mathrm{C}$ overnight in a nitrogen-filled glove box $\left(\mathrm{H}_{2} \mathrm{O}\right.$ and $\mathrm{O}_{2}<1$ ppm).

Fabrication of $\mathrm{CH}_{3} \mathrm{NH}_{3} \mathrm{PbI}_{3}$ Perovskite Solar Cells: A dense layer of $\mathrm{TiO}_{2}(\approx 40 \mathrm{~nm})$ was coated atop a UV-ozone cleaned F-doped tin-oxide (FTO)-coated glass substrate (a sheet resistance of $12 \Omega$ per square, $25 \mathrm{~mm} \times 25 \mathrm{~mm}$, Asahi Glass Co., Ltd., Japan) by spray-pyrolysis at $470{ }^{\circ} \mathrm{C}$ using a bis(isopropoxide)bis(acetylacetonato)titanium(IV) solution (75 wt\% in 2-propanol, Sigma-Aldrich) diluted in ethanol ( $1: 39$, volume ratio). To deposit perovskite films, these dense- $\mathrm{TiO}_{2}$ substrates were transferred into an inert glove box under a nitrogen atmosphere $\left(\mathrm{H}_{2} \mathrm{O}\right.$ and $\left.\mathrm{O}_{2}<1 \mathrm{ppm}\right)$. The $\mathrm{CH}_{3} \mathrm{NH}_{3} \mathrm{PbI}_{3}$ solution $(0.13 \mathrm{~mL})$ was first dropped onto the center of the FTO substrate coated with the dense- $\mathrm{TiO}_{2}$ layer. The substrate was firstly spun at 5000 rpm for $30 \mathrm{~s}$, and after $6 \mathrm{~s}$ anhydrous chlorobenzene (CB, 99.8\%, Sigma-Aldrich, $0.3 \mathrm{~mL}$ ) was quickly dropped onto the center of substrate. The instant color change of films from yellow to brown was observed upon dropping CB solvent. The resulting dark brown films were dried at $100{ }^{\circ} \mathrm{C}$ for $10 \mathrm{~min}$. The hole-transporting layer (HTL) was deposited on the perovskite layer 


\section{WILEY-VCH}

by spin-coating at different velocities, such as 1000, 2000, 4000, and $8000 \mathrm{rpm}$ for $30 \mathrm{~s}$ from a solution of $2,2^{\prime}, 7,7^{\prime}$-tetrakis( $N, N$-di-p-methoxyphenylamine)-9,9-spirobifluorene (spiroOMeTAD, Merck, $72.3 \mathrm{mg}$ ) in anhydrous chlorobenzene (CB, 99.8\%, Sigma-Aldrich, $1.0 \mathrm{~mL})$ containing $28.8 \mu \mathrm{L}$ of 4-tert-butylpyridine (Aldrich) and $17.5 \mu \mathrm{L}$ of lithium bis(trifluoromethanesulfonyl)imide (Li-TFSI) solution (520 mg Li-TFSI in $1 \mathrm{~mL}$ acetonitrile, Sigma-Aldrich). Finally, $80 \mathrm{~nm}$ of gold was thermally evaporated on top of the active layer under high vacuum $\left(2.5 \times 10^{-4} \mathrm{~Pa}\right)$. The final layered structure of these perovskite solar cells is $\mathrm{FTO} /$ dense- $\mathrm{TiO}_{2} / \mathrm{CH}_{3} \mathrm{NH}_{3} \mathrm{PbI}_{3} / \mathrm{HTL} / \mathrm{Au}$. At least 6 devices were fabricated to ensure the reproducibility of the $J-V$ characteristics

Measurements: $J-V$ characteristics were measured with a direct-current (DC) voltage and current source/monitor (Keithley, 2611B) in the dark and under the AM1.5G simulated solar illumination with $100 \mathrm{~mW} \mathrm{~cm}{ }^{-2}$. The light intensity was corrected with a calibrated silicon photodiode reference cell (Bunkoh-Keiki, BS-520). The intensity-dependent $J-V$ characteristics were measured by using the neutral density (ND) filters. The EQE spectra were measured with a spectral response measurement system (Bunko-Keiki Co., ECT-250D). The power of the incident monochromatic light was kept under $0.05 \mathrm{~mW} \mathrm{~cm}^{-2}$, which was measured by a calibrated silicon reference cell. All devices were measured in a nitrogen atmosphere with a metal mask to give an active area of $0.09 \mathrm{~cm}^{2}$. Note that averaged parameters are obtained from 12 devices with an HTL thickness of $170 \mathrm{~nm}$ and from 6 devices for the others to ensure the reproducibility of the $J-V$ characteristics. The film thickness were measured with an atomic force microscope (Shimadzu, SPM-9600) with a silicon probe (Olympus, a force constant of $\left.\approx 0.15 \mathrm{~N} \mathrm{~m}^{-1}\right)$ in contact mode. 


\section{WILEY-VCH}

\section{Supporting Information}

Supporting Information is available from the Wiley Online Library or from the author.

\section{Acknowledgments}

This study is based on the results obtained from a project commissioned by the New Energy and Industrial Technology Development Organization (NEDO) and partly supported by the Advanced Low Carbon Technology Research and Development (ALCA) program (Solar Cell and Solar Energy Systems) from the Japan Science and Technology Agency (JST). H. D. Kim also thanks Research Fellowships for Young Scientists (16J08768), the Japan Society for the Promotion of Science (JSPS).

Received: ((will be filled in by the editorial staff))

Revised: ((will be filled in by the editorial staff)) Published online: ((will be filled in by the editorial staff))

\section{References}

[1] S. D. Wolf, J. Holovsky, S.-J. Moon, P. Löper, B. Niesen, M. Ledinsky, F-J. Haug, J.-H. Yum, C. Ballif, J. Phys. Chem. Lett. 2014, 5, 1035.

[2] C. Wehrenfennig, G. E. Eperon, M. B. Johnston, H. J. Snaith, L. M. Herz, Adv. Mater. 2014, 26, 1584.

[3] M. A. Green, A. Ho-Baillie, H. J. Snaith, Nat. Photonics 2014, 8, 506.

[4] P. Gao, M. Grätzel, M. K. Nazeeruddin, Energy Environ. Sci. 2014, 7, 2448.

[5] S. D. Stranks, G. E. Eperson, G. Grancini, C. Menelaou, M. J. P. Alcocer, T. Leijtens, L. M. Herz, A. Petrozza, H. J. Snaith, Science 2013, 342, 341.

[6] N.-G. Park, M. Grätzel, T. Miyasaka, K. Zhu, K. Emery, Nat. Energy 2016, 1, 16152.

[7] H. D. Kim, H. Ohkita, H. Benten, S. Ito, Adv. Mater. 2016, 28, 917.

[8] W. S. Yang, J. H. Noh, N. J. Jeon, Y. C. Kim, S. Ryu, J. Seo, S. I. Seok, Science 2015, $348,1234$.

[9] N. Ahn, D.-Y. Son, I.-H. Jang, S. M. Kang, M. Choi, N.-G. Park, J. Am. Chem. Soc. 2015, $137,8696$.

[10] A. Kojima, K. Teshima, Y. Shirai, T. Miyasaka, J. Am. Chem. Soc. 2009, 131, 6050.

[11] Y. Zhou, K. Zhu, ACS Energy Lett. 2016, 1, 64. 


\section{WILEY-VCH}

[12] D. Bi, C. Yi, J. Luo, J.-D. Décoppet, F. Zhang, S. M. Zakeeruddin, X. Li, A. Hagfeldt, M. Grätzel, Nat. Energy 2016, 1, 16142.

[13] J. M. Ball, S. D. Stranks, M. T. Hörantner, S. Hüttner, W. Zhang, E. J. W. Crossland, I. Ramirez, M. Riede, M. B. Johnston, R. H. Friend, H. J. Snaith, Energy Environ. Sci. 2015, 8,602 .

[14] Z. Song, S. C. Watthage, A. B. Phillips, M. J. Heben, J. Photon. Energy 2016, 6, 022001.

[15] M. Ye, X. Hong, F. Zhang, X. Liu, J. Mater. Chem. A 2016, 4, 6755.

[16] F. Jiang, Y. Rong, H. Liu, T. Liu, L. Mao, W. Meng, F. Qin, Y. Jiang, B. Luo, S. Xiong, J. Tong, Y. Liu, Z. Li, H. Han, Y. Zhou, Adv. Funct. Mater. 2016, 26, 8119.

[17] M. Saliba, T. Matsui, K. Domanski, J.-Y. Seo, A. Ummadisingu, S. M. Zakeeruddin, J.P. Correa-Baena, W. R. Tress, A. Abate, A. Hagfeldt, M. Grätzel, Science 2016, 354, 206.

[18] A. R. B. M. Yusoff, M. K. Nazeeruddin, J. Phys. Chem. Lett. 2016, 7, 851.

[19] W. L. Leong, Z.-E. Ooi, D. Sabba, C. Yi, S. M. Zakeeruddin, M. Grätzel, J. M. Gordon, E. A. Katz, N. Mathews, Adv. Mater. 2016, 28, 2439.

[20] Y. Yamada, T. Nakamura, M. Endo, A. Wakamiya, Y. Kanemitsu, J. Am. Chem. Soc. 2014, 136, 11610.

[21] T. Leijtens, G. E. Eperon, A. J. Barker, G. Grancini, W. Zhang, J. M. Ball, A. R. S. Kandada, H. J. Snaith, A. Petrozza, Energy Environ. Sci. 2016, 9, 3472.

[22] K. Chen, Q. Hu, T. Liu, L. Zhao, D. Luo, J. Wu, Y. Zhang, W. Zhang, F. Liu, T. P. Russel, R. Zhu, Q. Gong, Adv. Mater. 2016, 28, 10718.

[23] C.-G. Wu, C.-H. Chiang, Z.-L. Tseng, M. K. Nazeeruddin, A. Hagfeldt, M. Grätzel, Energy Environ. Sci. 2015, 8, 2725.

[24] Z. Zhu, Y. Bai, X. Liu, C.-C. Chueh, S. Yang, A. K.-Y. Jen, Adv. Mater. 2016, 28, 6478.

[25] S. M. Sze, Physics of Semiconductor Devices 2nd ed., Wiley, New York, 1981.

[26] J. Nelson, The Physics of Solar Cells, Imperial College Press, London, 2003. 


\section{WILEY-VCH}

[27] A. Abate, T. Leijtens, S. Pathak, J. Teuscher, R. Avolio, M. E. Errico, J. Kirkpatrik, J. M. Ball, P. Docampo, I. McPherson, H. J. Snaith, Phys. Chem. Chem. Phys. 2013, 15, 2572.

[28] K. Wojciechowski, M. Saliba, T. Leijtens, A. Abate, H. J. Snaith, Energy Environ. Sci. 2014, $7,1142$.

[29] M. A. Green, Solid State Electron. 1981, 24, 788.

[30] M. A. Green, Sol. Cells 1982, 7, 337.

[31] B. Qi, J. Wang, Phys. Chem. Chem. Phys. 2013, 15, 8972.

[32] A. Mette, D. Pysch, G. Emanuel, D. Erath, R. Preu, S. W. Glunz, Prog. Photovoltaics: Res. Appl. 2007, 15, 493.

[33] J. H. Lee, Y. H. Lee, J. Y. Ahn, J.-W. Jeong, Sol. Energy Mater. Sol. Cells 2011, 95, 22.

[34] M. Hörteis, J. Bartsch, S. Binder, A. Filipovic, J. Merkel, V. Radtke, S. W. Glunz, Prog. Photovoltaics: Res. Appl. 2010, 18, 240.

[35] A. Mette, New Concepts for Front Side Metallization of Industrial Silicon Solar Cells, Ph.D. Thesis, Albert Ludwig University of Freiburg, November, 2007.

[36] W. H. Nguyen, C. D. Bailie, E. L. Unger, M. D. McGehee, J. Am. Chem. Soc. 2014, 136, 10996.

[37] K. Masuko, M. Shigematsu, T. Hashiguchi, D. Fujishima, M. Kai, N. Yoshimura, T. Yamaguchi, Y. Ichihashi, T. Mishima, N. Matsubara, T. Yamanishi, T. Takahama, M. Taguchi, E. Maruyama, S. Okamoto, IEEE J. Photovoltaics 2014, 4, 1433.

[38] J. A. Hornbeck, J. R. Haynes, Phys. Rev. 1955, 97, 311.

[39] J. R. Haynes, J. A. Hornbeck, Phys. Rev. 1955, 100, 606.

[40] I. Capan, V. Borjanović, B. Pivac, Sol. Energy Mater. Sol. Cells 2007, 91, 931. 
Figures and Figure Captions

a)

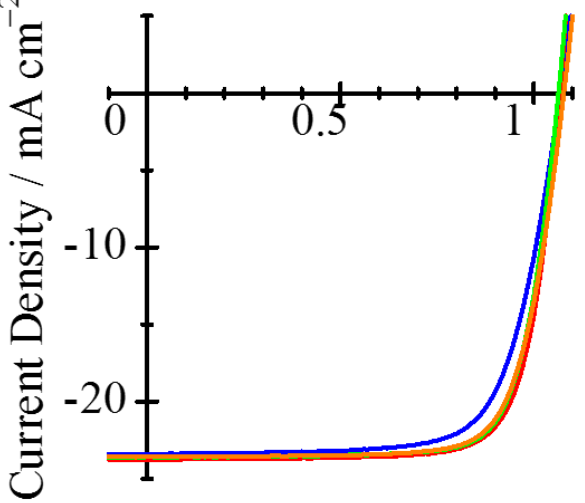

b)

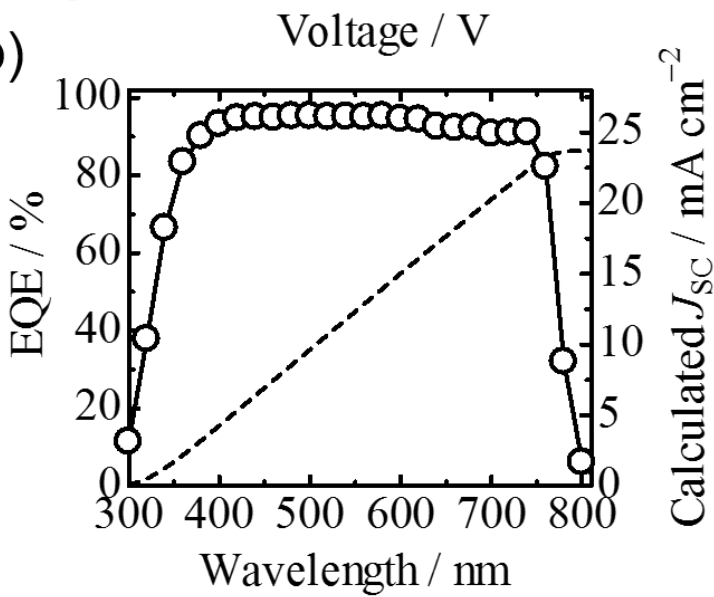

Figure 1. a) $J-V$ characteristics of $\mathrm{CH}_{3} \mathrm{NH}_{3} \mathrm{PbI}_{3}$ perovskite solar cells with different HTL thickness measured from 1.1 to $-0.10 \mathrm{~V}$ (reverse scan) with a delay time of $1 \mathrm{~s}$ : blue line (310 $\mathrm{nm})$, orange line $(230 \mathrm{~nm})$, red line $(170 \mathrm{~nm})$, and green line $(130 \mathrm{~nm})$ and b) EQE spectra (open circles) and $J_{\mathrm{SC}}$ (broken lines) calculated from the EQE and solar spectra of the best device studied. 

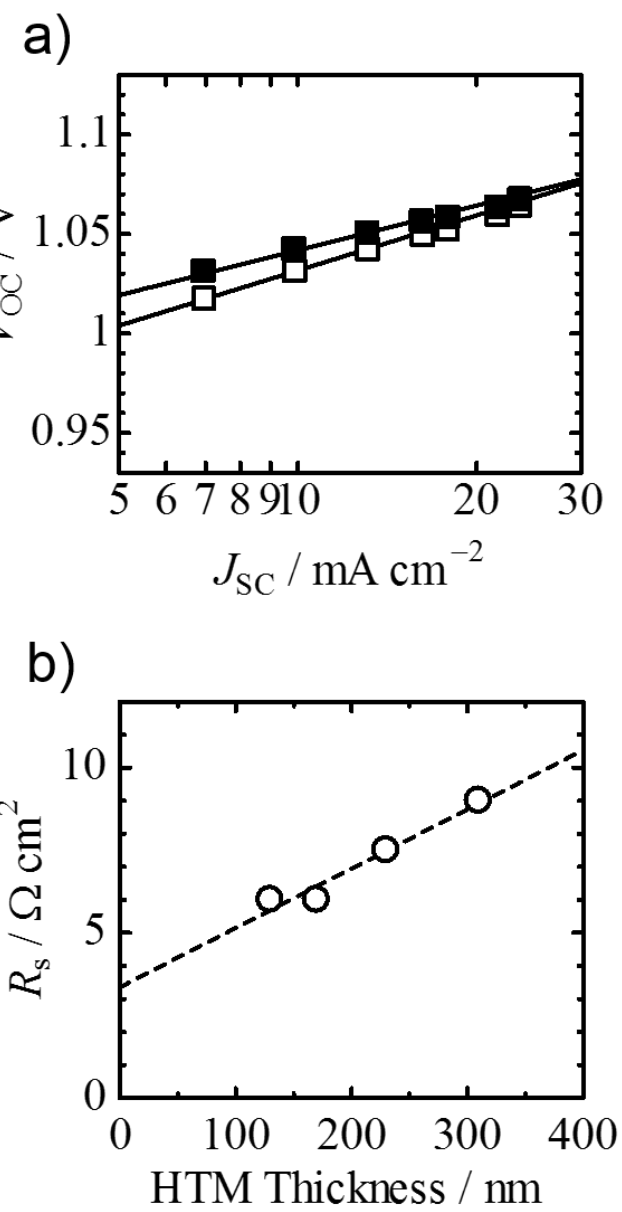

Figure 2. a) $V_{\mathrm{OC}}$ plotted against the logarithm of $J_{\mathrm{SC}}$ in the devices with an HTL thickness of $170 \mathrm{~nm}$ : forward scan (open squares) and reverse scan (close squares) and b) $R_{\mathrm{s}}$ plotted against the HTL thickness. The solid lines in the panel (a) are drawn by using Equation (2): the slope is 1.6 for the forward scan and 1.3 for the reverse scan. The broken line in the panel (b) represents a linear fit to the experimental data. 


\section{WILEY-VCH}

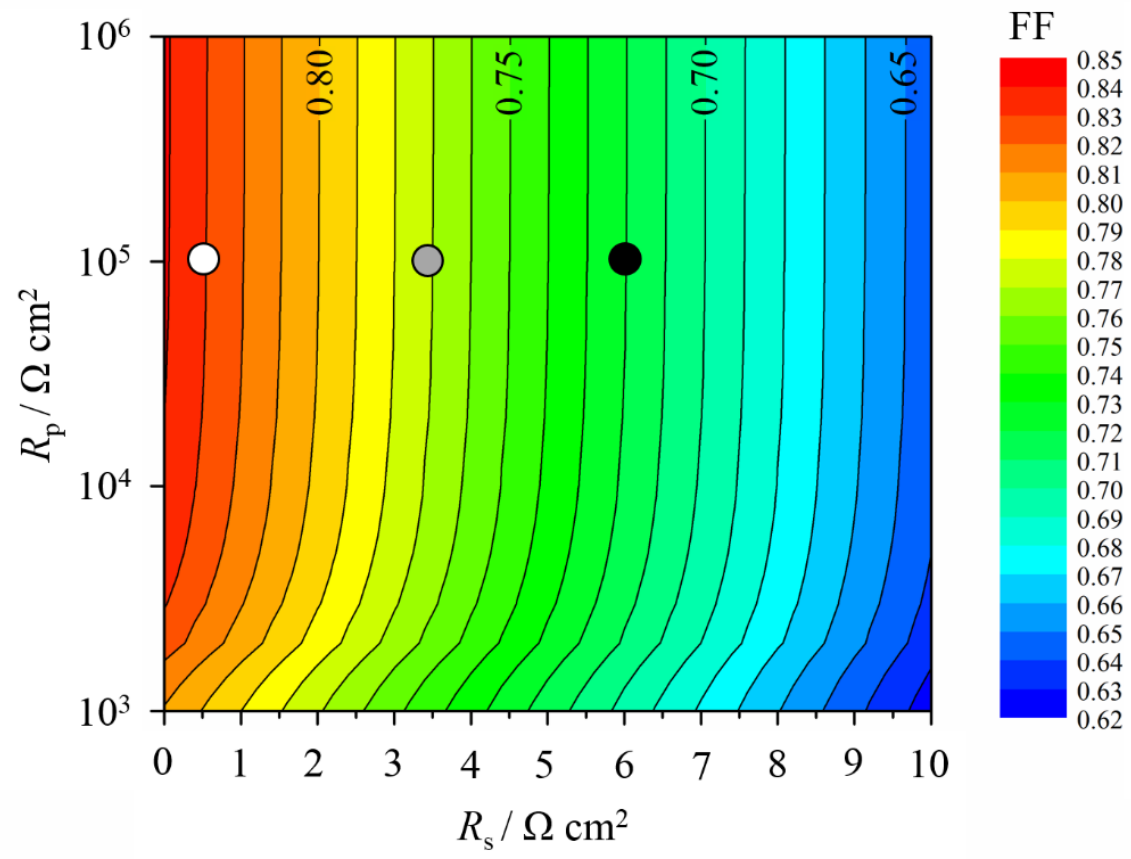

Figure 3. Contour map of FF calculated by Equation (4) with different $R_{\mathrm{s}}$ and $R_{\mathrm{p}}$ resistances. In this calculation, the photovoltaic parameters were employed for the best device measured under the forward scan: $J_{\mathrm{SC}}=23.8 \mathrm{~mA} \mathrm{~cm}^{-2}, V_{\mathrm{OC}}=1.06 \mathrm{~V}$, and $n_{\mathrm{id}}=1.6$. The close, gray closed, and open circles indicate the FF for the best device experimentally measured under the forward scan, that calculated with $R_{\mathrm{s}}=3.4 \Omega \mathrm{cm}^{2}$ and $R_{\mathrm{p}}=1.0 \times 10^{5} \Omega \mathrm{cm}^{2}$, and that calculated with $R_{\mathrm{s}}$ $=0.5 \Omega \mathrm{cm}^{2}$ and $R_{\mathrm{p}}=1.0 \times 10^{5} \Omega \mathrm{cm}^{2}$. 


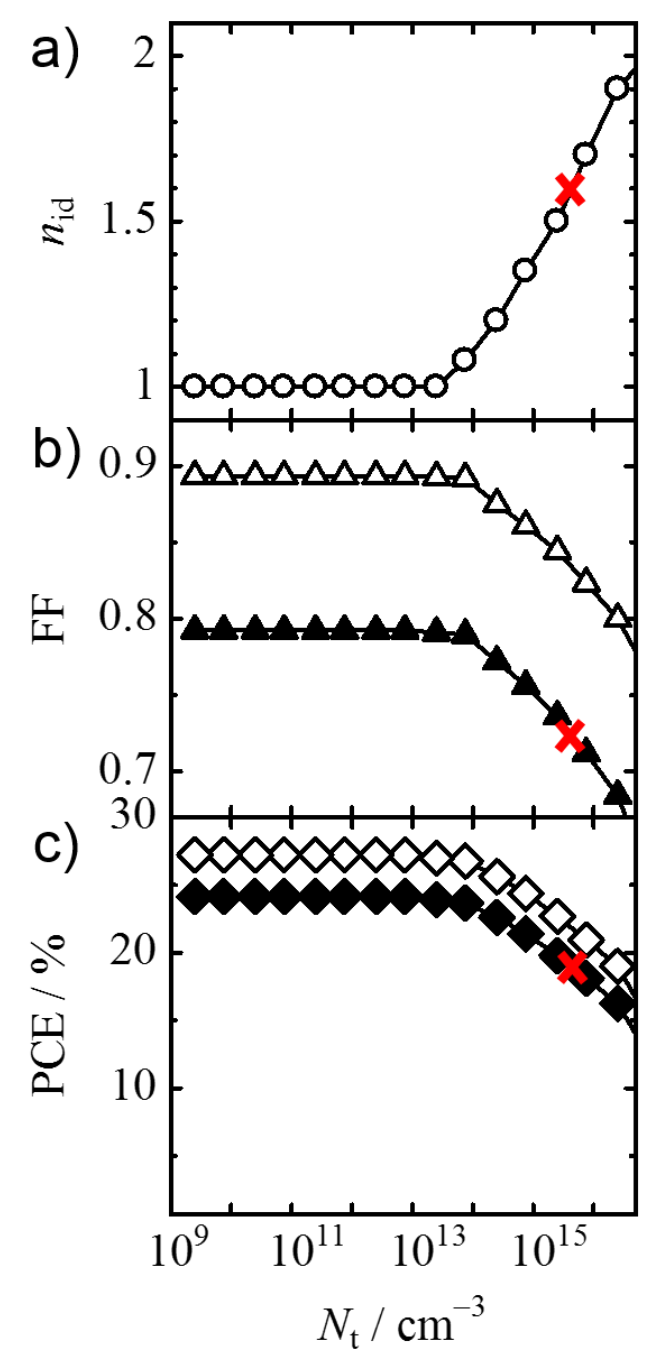

Figure 4. a) $n_{\text {id, }}$ b) FF, and c) PCE plotted against the logarithm of $N_{\mathrm{t}}$ for $\mathrm{CH}_{3} \mathrm{NH}_{3} \mathrm{PbI}_{3}$ perovskite solar cells with different resistances: $\mathrm{CH}_{3} \mathrm{NH}_{3} \mathrm{PbI}_{3}$ perovskite solar cells with $R_{\mathrm{S}}=$ $6.0 \Omega \mathrm{cm}^{2}$ and $R_{\mathrm{p}}=1.0 \times 10^{5} \Omega \mathrm{cm}^{2}$ (close triangles and diamonds) and $\mathrm{CH}_{3} \mathrm{NH}_{3} \mathrm{PbI}_{3}$ perovskite solar cells with $R_{\mathrm{S}}=0.5 \Omega \mathrm{cm}^{2}$ and $R_{\mathrm{p}}=1.0 \times 10^{5} \Omega \mathrm{cm}^{2}$ (open triangles and diamonds). "X" marks represent the photovoltaic parameters for the best device measured under the forward scan. 


\section{WILEY-VCH}

Table 1. Photovoltaic parameters of $\mathrm{CH}_{3} \mathrm{NH}_{3} \mathrm{PbI}_{3}$ perovskite solar cells with different HTL thickness measured from 1.1 to $-0.10 \mathrm{~V}$ (reverse scan) with a delay time of $1 \mathrm{~s}$. All the devices were measured in a nitrogen atmosphere with a metal mask to give an active area of $0.09 \mathrm{~cm}^{2}$.

\begin{tabular}{ccccc}
\hline HTL thickness $[\mathrm{nm}]^{\mathrm{a})}$ & $\mathrm{JSC}_{\mathrm{SC}}\left[\mathrm{mA} \mathrm{cm}^{-2}\right]$ & $V_{\mathrm{OC}}[\mathrm{V}]$ & $\mathrm{FF}$ & PCE $[\%]$ \\
\hline 130 & $23.6(23.5 \pm 0.08)$ & $1.06(1.06 \pm 0.00)$ & $0.768(0.759 \pm 0.01)$ & $19.2(18.9 \pm 0.22)$ \\
170 & $23.8(23.7 \pm 0.10)$ & $1.07(1.07 \pm 0.01)$ & $0.770(0.760 \pm 0.01)$ & $19.6(19.2 \pm 0.27)$ \\
230 & $23.5(23.5 \pm 0.05)$ & $1.08(1.07 \pm 0.01)$ & $0.753(0.746 \pm 0.01)$ & $19.1(18.8 \pm 0.18)$ \\
310 & $23.4(23.5 \pm 0.21)$ & $1.07(1.07 \pm 0.01)$ & $0.720(0.716 \pm 0.00)$ & $18.0(17.9 \pm 0.25)$ \\
\hline
\end{tabular}

a) The values represent the best photovoltaic parameters in the $\mathrm{CH}_{3} \mathrm{NH}_{3} \mathrm{PbI}_{3}$ perovskite solar cells with different HTL thicknesses. The photovoltaic parameters in parentheses are averaged for at least 6 devices.

Table 2. Diode parameters of $\mathrm{CH}_{3} \mathrm{NH}_{3} \mathrm{PbI}_{3}$ perovskite solar cells with different HTL thicknesses.

\begin{tabular}{ccccc}
\hline $\mathrm{HTL}$ thickness $[\mathrm{nm}]$ & Scan direction & $n_{\mathrm{id}}^{\mathrm{a})}$ & $R_{\mathrm{s}}\left[\Omega \mathrm{cm}^{2}\right]^{\mathrm{b})}$ & $R_{\mathrm{p}}\left[\Omega \mathrm{cm}^{2}\right]^{\mathrm{b})}$ \\
\hline \multirow{2}{*}{130} & Forward & 1.6 & 6.0 & $2.0 \times 10^{5}$ \\
& Reverse & 1.3 & 6.0 & $2.0 \times 10^{5}$ \\
\multirow{2}{*}{170} & Forward & 1.6 & 6.0 & $1.0 \times 10^{5}$ \\
& Reverse & 1.3 & 6.0 & $1.2 \times 10^{5}$ \\
\multirow{2}{*}{230} & Forward & 1.6 & 7.5 & $8.0 \times 10^{5}$ \\
\multirow{2}{*}{310} & Reverse & 1.3 & 7.5 & $3.0 \times 10^{5}$ \\
& Forward & 1.6 & 9.0 & $2.0 \times 10^{5}$ \\
& Reverse & 1.3 & 9.0 & $1.2 \times 10^{5}$ \\
\hline
\end{tabular}

a) The $n_{\text {idS }}$ are evaluated from a slope in $V_{\text {OC }}$ plotted against the logarithm of $J_{\mathrm{SC}}$ based on Equation (2). ${ }^{\text {b) }}$ Both $R_{\mathrm{S}}$ and $R_{\mathrm{p}}$ resistances are obtained from the slope of the $J-V$ charateristics in the dark. 


\section{WILEY-VCH}

Table 3. FF measured and calculated for $\mathrm{CH}_{3} \mathrm{NH}_{3} \mathrm{PbI}_{3}$ perovskite solar cells with different HTL thicknesses as a function of the scan directions.

\begin{tabular}{ccccc}
\hline $\mathrm{HTL}$ thickness $[\mathrm{nm}]$ & Scan direction & $\mathrm{FF}_{\text {exp }}$ & $\mathrm{FF}_{\text {cal }}$ & Error [\%] \\
\hline \multirow{2}{*}{130} & Forward & 0.710 & 0.72 & 1.4 \\
& Reverse & 0.768 & 0.74 & 3.8 \\
170 & Forward & 0.720 & 0.72 & 0 \\
& Reverse & 0.770 & 0.74 & 4.1 \\
230 & Forward & 0.688 & 0.69 & 0.29 \\
& Reverse & 0.753 & 0.71 & 6.0 \\
\multirow{2}{*}{310} & Forward & 0.666 & 0.67 & 0.60 \\
& Reverse & 0.720 & 0.68 & 5.9 \\
\hline
\end{tabular}

Table 4. Present and predicted photovoltaic parameters with various $N_{\mathrm{t}}$ and the diode parameters.

\begin{tabular}{|c|c|c|c|c|c|}
\hline \multirow{2}{*}{$\begin{array}{c}\text { Device } \\
\text { parameters }\end{array}$} & \multicolumn{4}{|c|}{ Perovskite devices } & \multirow{2}{*}{$\begin{array}{l}\text { Crystalline silicon } \\
\text { devices }^{[32-35,37-40]}\end{array}$} \\
\hline & Present $^{\text {a) }}$ & Low $R_{\mathrm{s}}$ & Low $N_{t}$ & Low $N_{\mathrm{t}}$ and $R_{\mathrm{s}}$ & \\
\hline$N_{\mathrm{t}}\left[\mathrm{cm}^{-3}\right]$ & $\approx 10^{15}$ & $\approx 10^{15}$ & $<10^{13}$ & $<10^{13}$ & $<10^{13}$ \\
\hline$n_{\text {id }}$ & 1.6 & 1.6 & 1 & 1 & 1 \\
\hline$R_{\mathrm{s}}\left[\Omega \mathrm{cm}^{2}\right]$ & 6.0 & 0.5 & 6.0 & 0.5 & 0.5 \\
\hline$R_{\mathrm{p}}\left[\Omega \mathrm{cm}^{2}\right]$ & $1.0 \times 10^{5}$ & $1.0 \times 10^{5}$ & $1.0 \times 10^{5}$ & $1.0 \times 10^{5}$ & $\approx 10^{4}$ \\
\hline$J_{\mathrm{SC}}\left[\mathrm{mA} \mathrm{cm} \mathrm{cm}^{-2}\right]$ & 23.8 & 24 & 24 & 24 & 41.8 \\
\hline$V_{O C}[\mathrm{~V}]$ & 1.06 & 1.06 & 1.27 & 1.27 & 0.740 \\
\hline FF & 0.720 & 0.83 & 0.79 & 0.89 & 0.827 \\
\hline PCE [\%] & 18.2 & 21 & 24 & 27 & 25.6 \\
\hline
\end{tabular}

a) The values represent the best device measured under the forward scan. 


\section{WILEY-VCH}

The limiting factors in fill factor (FF) of perovskite solar cells are discussed by using an empirical equation based on different thickness of a hole-transporting layer. The FF is primarily dependent on the series resistance and trap density in perovskite devices. The potential strategies for the improvements in FF and PCE are further discussed based on the experimental data.

Keyword: organic-inorganic perovskites, fill factors, series resistances, parallel resistances, ideality factors

Hyung Do Kim and Hideo Ohkita*

\section{Potential Improvement in Fill Factor of Lead-Halide Perovskite Solar Cells}

ToC figure ((Please choose one size: $55 \mathrm{~mm}$ broad $\times 50 \mathrm{~mm}$ high or $110 \mathrm{~mm}$ broad $\times 20 \mathrm{~mm}$ high. Please do not use any other dimensions))

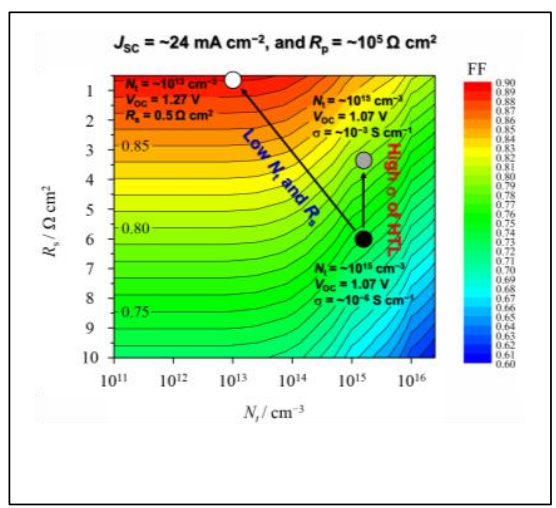




\section{WILEY-VCH}

Copyright WILEY-VCH Verlag GmbH \& Co. KGaA, 69469 Weinheim, Germany, 2016.

\section{Supporting Information}

\section{Potential Improvement in Fill Factor of Lead-Halide Perovskite Solar Cells}

Hyung Do Kim and Hideo Ohkita*

H. D. Kim and Prof. H. Ohkita

Department of Polymer Chemistry

Graduate School of Engineering

Kyoto University

Katsura, Nishikyo, Kyoto 615-8510, Japan

E-mail: ohkita@photo.polym.kyoto-u.ac.jp 


\section{Hysteresis in $\mathrm{CH}_{3} \mathrm{NH}_{3} \mathrm{PbI}_{3}$ Perovskite Solar Cells}

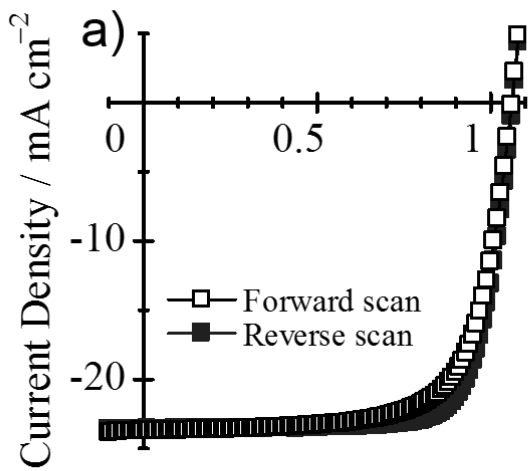

Voltage / V

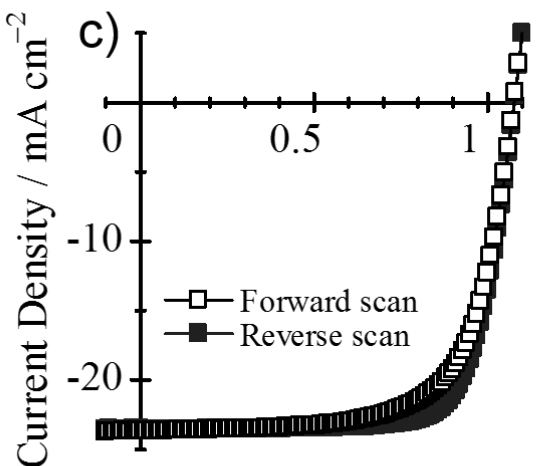

Voltage / V

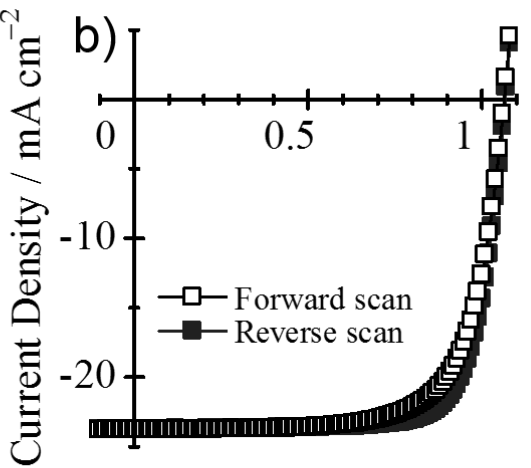

Voltage / V

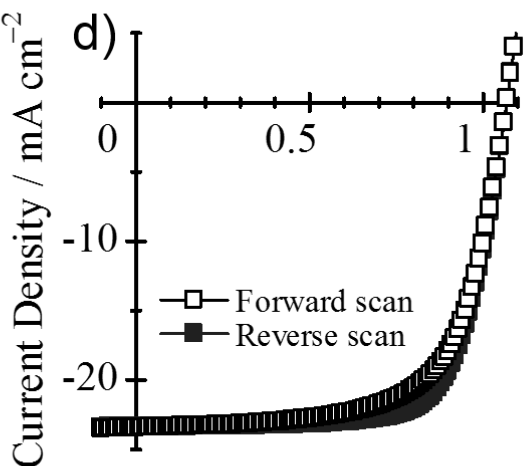

Voltage / V

Figure S1. a) $J-V$ characteristics of $\mathrm{CH}_{3} \mathrm{NH}_{3} \mathrm{PbI}_{3}$ perovskite solar cells with different HTL thicknesses measured from -0.10 to $1.1 \mathrm{~V}$ (forward scan) and from 1.1 to $-0.10 \mathrm{~V}$ (reverse scan) with a delay time of $1 \mathrm{~s}$ : a) $130 \mathrm{~nm}$, b) $170 \mathrm{~nm}$, c) $230 \mathrm{~nm}$, and d) $310 \mathrm{~nm}$. All the devices were measured in a nitrogen atmosphere with a metal mask to give an active area of $0.09 \mathrm{~cm}^{2}$. 


\section{Evaluation of the Ideality Factor $\left(n_{\text {id }}\right)$}
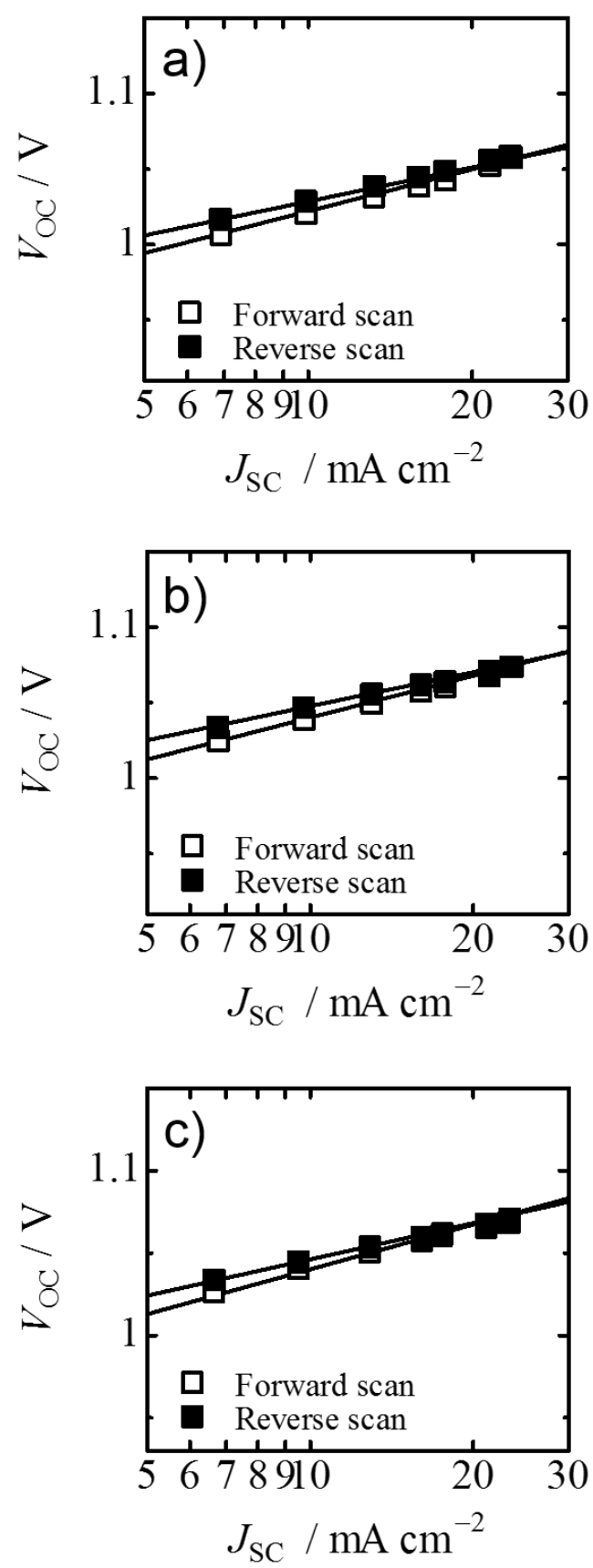

Figure S2. $V_{\mathrm{OC}}$ plotted against the logarithm of $J_{\mathrm{SC}}$ in $\mathrm{CH}_{3} \mathrm{NH}_{3} \mathrm{PbI}_{3}$ perovskite solar cells with different HTL thicknesses: a) $130 \mathrm{~nm}$, b) $230 \mathrm{~nm}$, and c) $310 \mathrm{~nm}$. The solid lines are drawn by using Equation (2): the slope is 1.6 for the forward scan and 1.3 for the reverse scan for all the panels. 


\section{WILEY-VCH}

\section{3. $J-V$ Characteristics in the Dark}
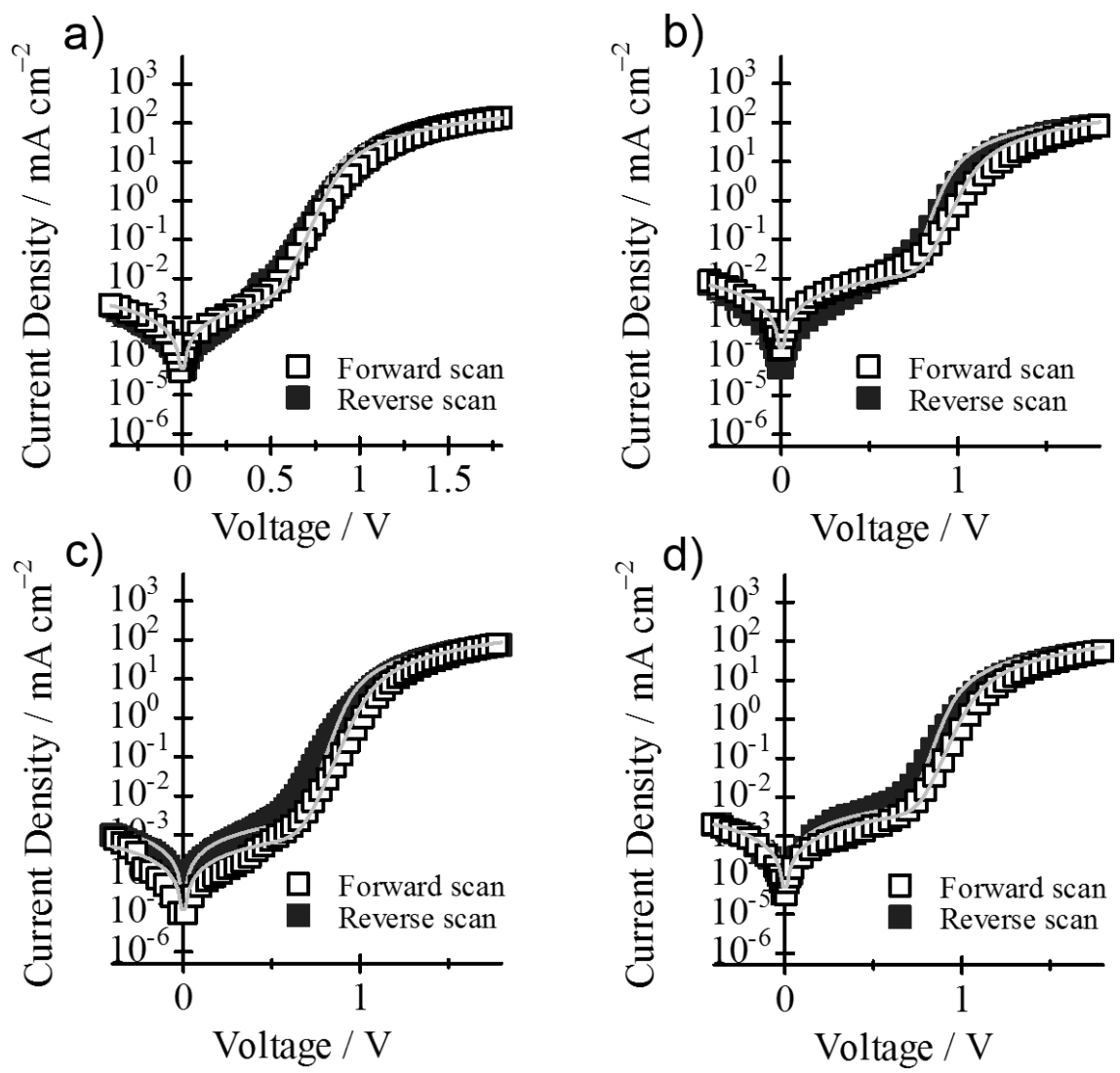

Figure S3. Logarithm of the dark current density plotted against the applied voltage in $\mathrm{CH}_{3} \mathrm{NH}_{3} \mathrm{PbI}_{3}$ perovskite solar cells with different HTL thicknesses: a) $\left.130 \mathrm{~nm}, \mathrm{~b}\right) 170 \mathrm{~nm}$, c) $230 \mathrm{~nm}$, and d) $310 \mathrm{~nm}$. The gray solid lines are extracted by a fit to the experimental data with Equation (1) on the basis of $n_{\text {id }}$ evaluated separately. 


\section{WILEY-VCH}

4. Thickness Dependence of $R_{s}$ in Au/spiro-OMeTAD/Au Configuration.

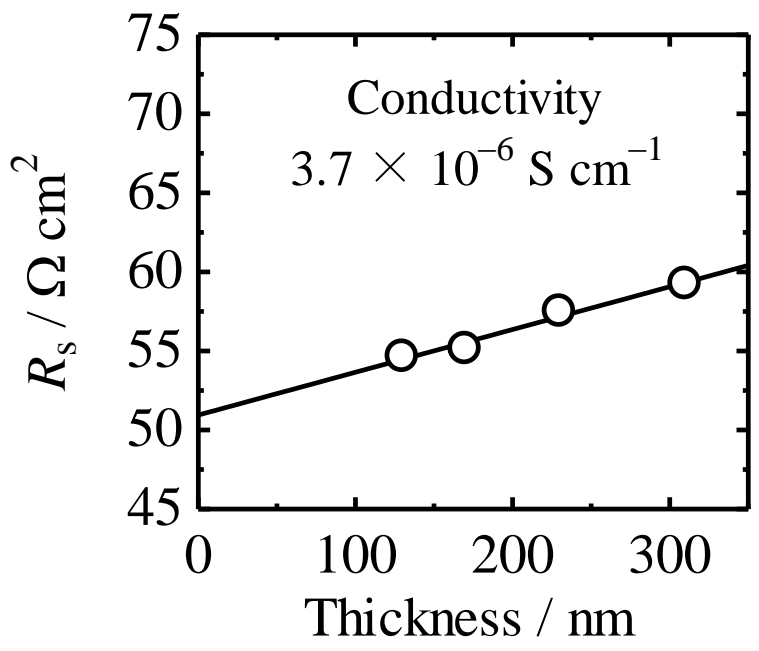

Figure S4. Series resistance plotted against the thickness of spiro-OMeTAD films in the configuration of Au/spiro-OMeTAD/Au. The solid line represents a linear fit to the experimental data. 


\section{WILEY-VCH}

\section{Contour Map of FF}
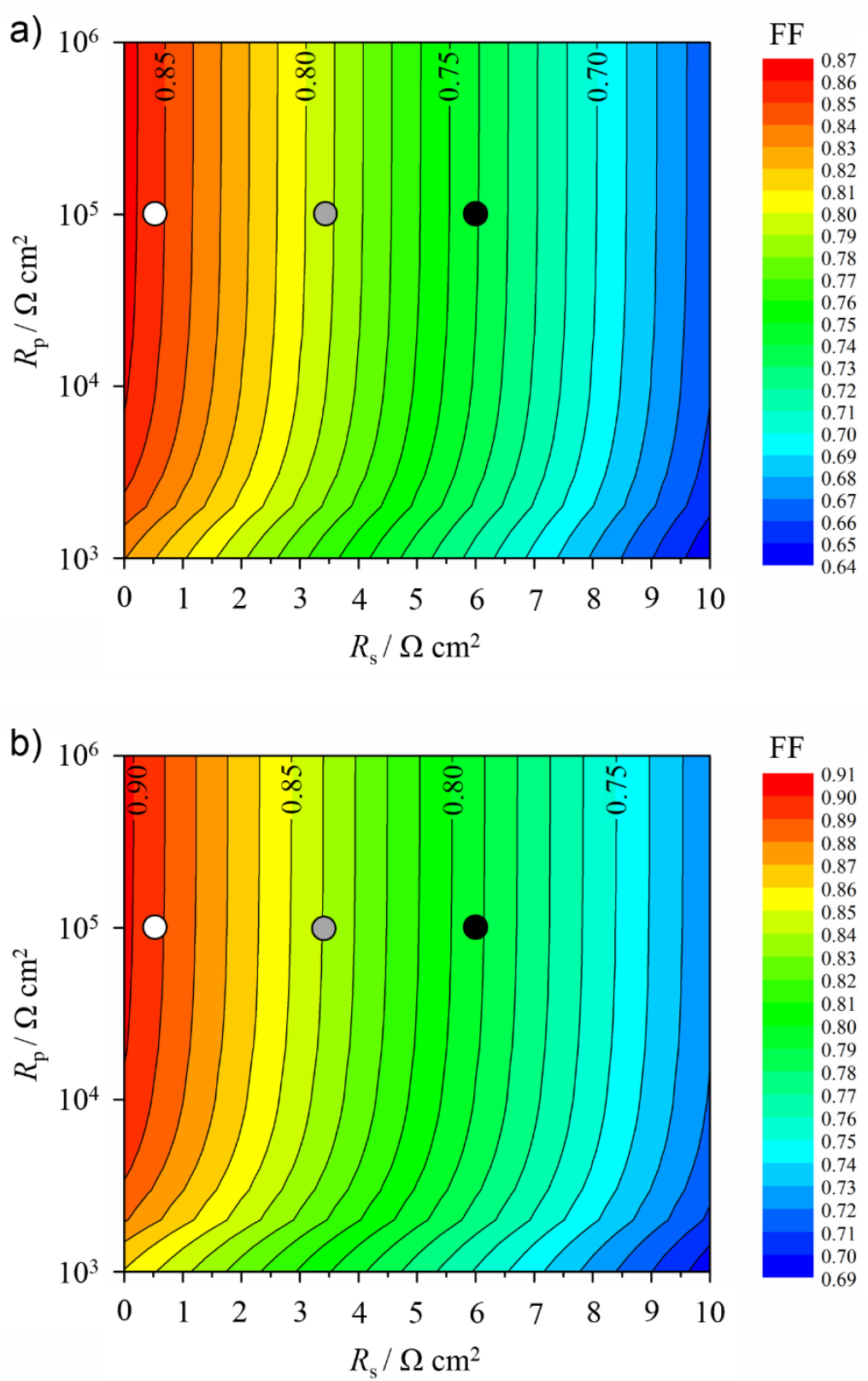

Figure S5. Contour map of FF calculated by Equation (4) with different $R_{\mathrm{S}}$ and $R_{\mathrm{p}}$ resistances. In this calculation, a) the photovoltaic parameters were employed for the best device measured under the reverse scan: $J_{\mathrm{SC}}=23.8 \mathrm{~mA} \mathrm{~cm}^{-2}, V_{\mathrm{OC}}=1.07 \mathrm{~V}$, and $n_{\mathrm{id}}=1.3$. b) the photovoltaic parameters were employed for the perovskite device with $N_{\mathrm{t}}$ of $<10^{13} \mathrm{~cm}^{-3}: J_{\mathrm{SC}}=24 \mathrm{~mA} \mathrm{~cm}{ }^{-2}$, $V_{\mathrm{OC}}=1.27 \mathrm{~V}$, and $n_{\mathrm{id}}=1.0$. The close, gray closed, and open circles indicate the FF for the best device experimentally measured under reverse scan, that calculated with $R_{\mathrm{S}}=3.4 \Omega \mathrm{cm}^{2}$ and $R_{\mathrm{p}}=1.0 \times 10^{5} \Omega \mathrm{cm}^{2}$, and that calculated with $R_{\mathrm{s}}=0.5 \Omega \mathrm{cm}^{2}$ and $R_{\mathrm{p}}=1.0 \times 10^{5} \Omega \mathrm{cm}^{2}$. 


\section{WILEY-VCH}

6. Series Resistance Plotted against the Logarithm of HTL Conductivity

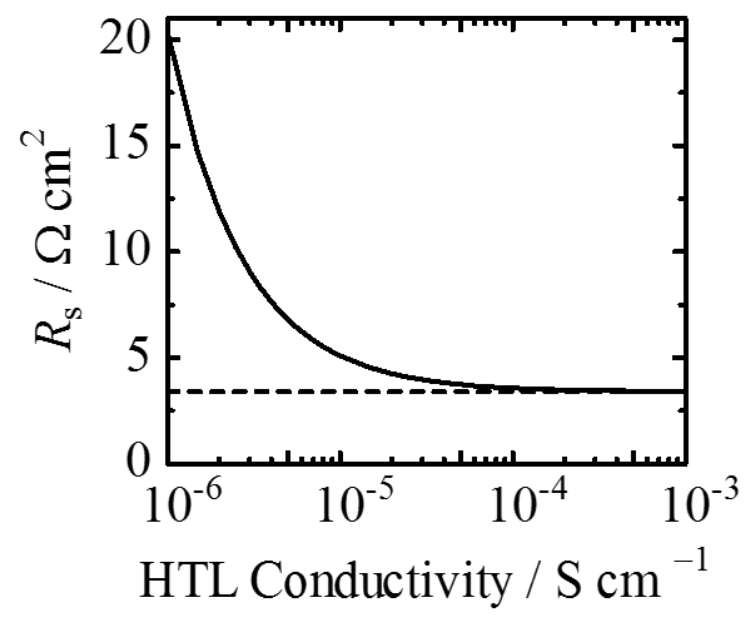

Figure S6. Series resistance plotted against the logarithm of HTL conductivity. The broken line represents the remaining constant component $\left(3.4 \Omega \mathrm{cm}^{2}\right)$ in the Figure $2 \mathrm{~b}$. 


\section{FF Measured and Calculated for Perovskite Solar Cells}

\section{WILEY-VCH}

Table S1. FF calculated for $\mathrm{CH}_{3} \mathrm{NH}_{3} \mathrm{PbI}_{3}$ perovskite solar cells with a different $V_{\mathrm{OC}}$.

\begin{tabular}{|c|c|c|c|c|c|c|c|c|c|}
\hline$N_{\mathrm{t}}\left[\mathrm{cm}^{-3}\right]^{\mathrm{a})}$ & $n_{\text {id }}^{\text {a) }}$ & $J_{\mathrm{sc}}\left[\mathrm{mA} \mathrm{cm}^{-2}\right]^{\mathrm{a})}$ & $V_{O C}[\mathrm{~V}]^{\mathrm{a})}$ & $\mathrm{FF}$ a) & Method $^{\text {b) }}$ & $R_{\mathrm{s}}\left[\Omega \mathrm{cm}^{2}\right]$ & $R_{\mathrm{p}}\left[\Omega \mathrm{cm}^{2}\right]$ & $\mathrm{FF}_{\text {cal }}$ & Error [\%] \\
\hline$\approx 5.0 \times 10^{16}$ & 2.7 & 17.0 & 1.00 & 0.60 & $\begin{array}{c}\text { Dark } \\
\end{array}$ & 6.0 & & 0.62 & $\begin{array}{l}3.3 \\
3.3\end{array}$ \\
\hline$\approx 1.0 \times 10^{16}$ & 2.0 & 22.1 & 1.04 & 0.73 & $\begin{array}{c}\text { Dark } \\
\text { Illumination }\end{array}$ & $\begin{array}{l}6.1 \\
4.7\end{array}$ & $\begin{array}{l}1.0 \times 10^{5} \\
7.3 \times 10^{3}\end{array}$ & $\begin{array}{l}.02 \\
0.70 \\
0.72\end{array}$ & $\begin{array}{l}0.0 \\
4.3 \\
1.4\end{array}$ \\
\hline$\approx 3.0 \times 10^{15}$ & 1.5 & 23.9 & 1.08 & 0.75 & $\begin{array}{l}\text { Dark } \\
\text { Illumination }\end{array}$ & $\begin{array}{l}6.0 \\
4.9\end{array}$ & $\begin{array}{l}1.0 \times 10^{5} \\
3.9 \times 10^{3}\end{array}$ & $\begin{array}{l}0.73 \\
0.74\end{array}$ & $\begin{array}{l}2.7 \\
1.4\end{array}$ \\
\hline
\end{tabular}

${ }^{\text {a) }} N_{\mathrm{t}}, n_{\text {id }}$, and photovoltaic parameters are taken from the previous literature. ${ }^{[\mathrm{S} 1]}$

b) $R_{\mathrm{s}}$ and $R_{\mathrm{p}}$ resistances are evaluated from the $J-V$ charateristics in the dark and under illumination. 


\section{WILEY-VCH}

\section{Reference}

[S1] H. D. Kim, H. Ohkita, H. Benten, S. Ito, Adv. Mater. 2016, 28, 917. 